\title{
Intensity of geodynamic processes in the Lithuanian part of the Curonian Spit
}

\author{
Algimantas Česnulevičius ${ }^{1}$, Regina Morkūnaitè ${ }^{2}$, Artūras Bautrènas ${ }^{1}$, Linas Bevainis ${ }^{1}$, and \\ Donatas Ovodas ${ }^{1}$ \\ ${ }^{1}$ Department of Cartography and Geoinformatics, Faculty of Chemistry and Geosciences, Vilnius University, \\ 03101, Vilnius, Lithuania \\ ${ }^{2}$ Laboratory of Quaternary Research, Institute of Geology and Geography, Nature Research Centre, \\ 08412, Vilnius, Lithuania
}

Correspondence to: Algimantas Česnulevičius (algimantas.cesnulevicius@gf.vu.lt)

Received: 5 January 2017 - Discussion started: 9 January 2017

Revised: 4 May 2017 - Accepted: 10 May 2017 - Published: 28 June 2017

\begin{abstract}
The paper considers conditions and intensity of aeolian and dune slope transformation processes occurring in the wind-blown sand strips of the dunes of the Curonian Spit. An assessment of the intensity of aeolian processes was made based on the analysis of climatic factors and in situ observations. Transformations in aeolian relief forms were investigated based on the comparison of geodetic measurements and measurements of aerial photographs. Changes in micro-terraces of dune slopes were investigated through comparison of the results of repeated levelling and measurements of aerial photographs. The periods of weak, medium, and strong winds were distinguished, and sand moisture fluctuations affecting the beginning of aeolian processes were investigated. The wind-blown sand movements were found to start when sand moisture decreased by $2 \%$ in the surface sand layer and by up to $5 \%$ at a depth of $10 \mathrm{~cm}$. In 2004-2016, the wind-blown sand movements affected the size of reference deflation relief forms: scarp length by $8 \%$, scarp width by $35 \%$, pothole length by $80 \%$, pothole width by $80 \%$, roll length by $17 \%$, roll width by $18 \%$, hollow length by $17 \%$, and hollow width by $39 \%$. The elementary relief forms in the leeward eastern slopes of the dunes experienced the strongest transformations. During a period of 5 months, the height of micro-terraces of the eastern slope of the Parnidis Dune changed from 0.05 to $0.64 \mathrm{~cm}$. The change was related to fluctuations in precipitation intensity: in JulyAugust 2016 the amount of precipitation increased 1.6-fold compared with the multiannual average, thus causing the change in the position of terrace ledges by $21 \%$.
\end{abstract}

\section{Introduction}

The formation of the core of the Curonian Spit started 68 thousand years ago and is related to the end of the third transgression of the Littorina (L3, III bl) Sea. The further development of the spit took place during the Post-Littorina $\mathrm{L}$ 4 (IV PL) period (Bitinas et al., 2001; Bitinas and Damušyte, 2004). Southward transportation of sand formed a shallow littoral zone on the south-eastern coast of the Baltic Sea. In the zone, fine- and medium-grained sand was drifted against glacigenic hills and onto emerged sand, grain, and pebble shallows of marine origin (Bitinas and Damušytè, 2004; Bitinas et al., 2005) (Fig. 1).

Favourable conditions for the formation of the spit and its dunes occurred before the start of the third stage of transgression of the Littorina Sea, when water level on the southeastern coast was 6-7 $\mathrm{m}$ lower compared to the today's water level. With water level rising, the Semba Peninsula suffered severe erosion and sediments were transported northwards. The germ of the spit formed near Šarkuva settlement (phase I); it reached Rasyte Island and grew further (phase II). Four to 4.5 thousand years ago, the spit extended up to Juodkrante settlement (phase III), and 2 thousand years 


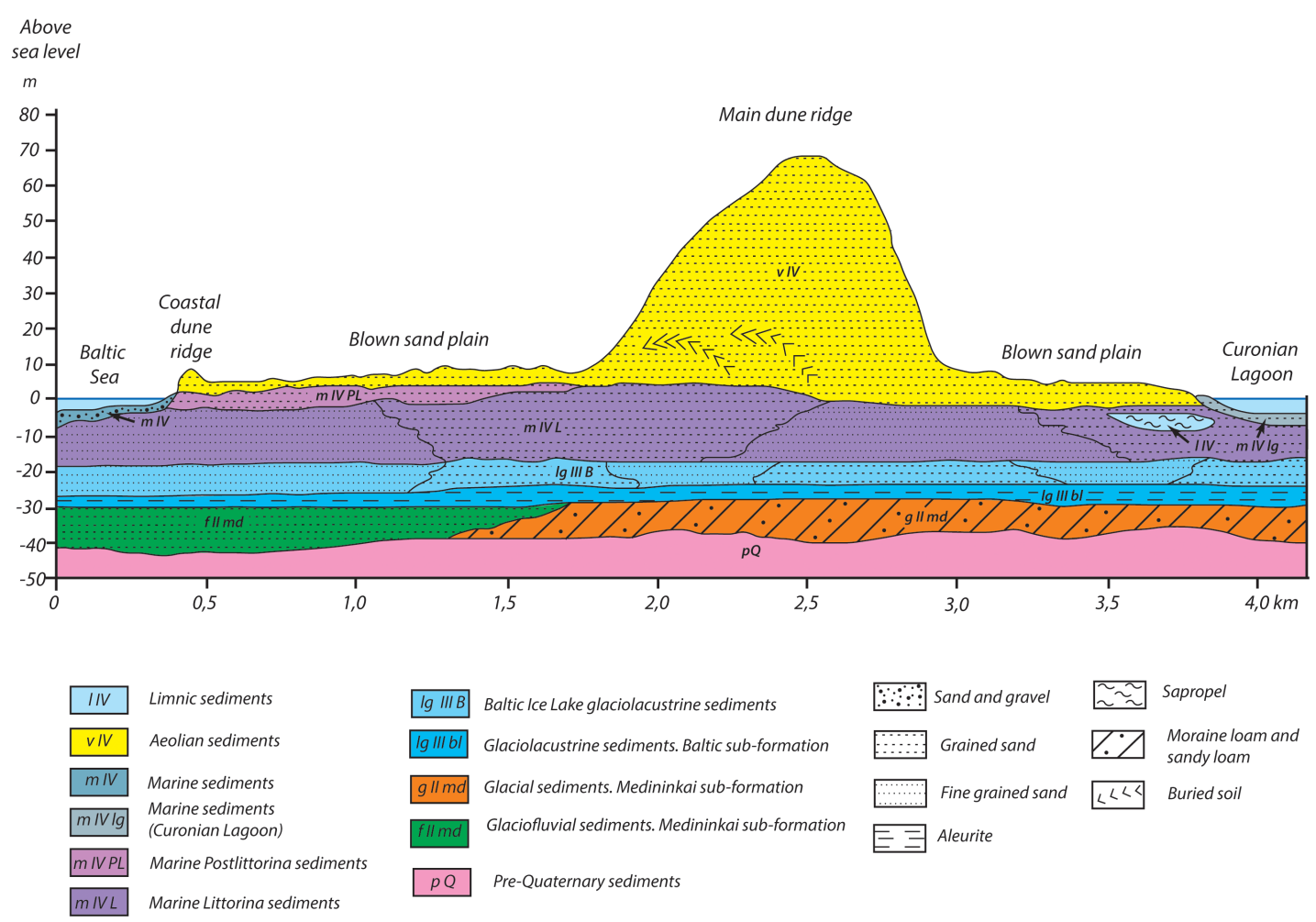

Figure 1. Cross section in the northern part of the Curonian Spit (Vingiakope environment) (by Bitinas et al., 2002; Badyukova et al., 2007).
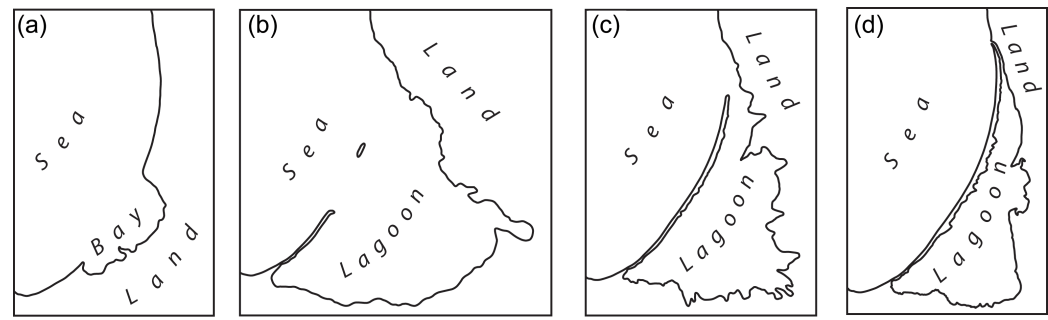

Figure 2. Curonian Spit evolution phases: (a) beginning of the third stage of Littorina Sea transgression (4 kyr BC), (b) end of Littorina Sea transgression (3 kyr BC), (c) Mya Sea transgression (2 kyr BC), and (d) contemporary Baltic Sea and Curonian Lagoon (Karte des Deutschen Reiches, 1911; Gudelis, 1998; Kabailiene, 1967; Kunskas, 1970).

ago, it reached the continental coast (stage IV) (Gudelis, 1979, 1998; Kabailiene, 1967; Kunskas, 1970; Kliewe and Janke, 1982; Mojski, 1988; Müller, 2004; Starkel, 1977) (Fig. 2).

Wind-blown sand movement is the main geomorphological geodynamic process that currently occurs in the Curonian Spit. Since the 16th century, 14 villages have been entirely buried under the sand, and dwellers of other villages had to move from one place to another to escape wind-blown sand (Fig. 3). The first efforts to slow down wind-blown sand movement go back to the first half of the 19th century, when dunes started to be overgrown with vegetation, which stabilized strong movement of sand throughout the 19th century. The first scientific research into aeolodynamic processes in the Curonian Spit appeared in the second half of the 19th century (Berendt, 1869). Since the middle of the 20th century, the Curonian Spit has become an object of comprehensive investigations by Lithuanian geographers who put their main focus on the morphogenesis of dunes and the mineral and granulometric composition of sand (Gaigalas and Pazdur, 2008; Gudelis, 1998; Mardosienè, 1988; Michaliukaitè, 1967; Minkevičius, 1982; Minkevičius et al., 1996). Though by the end of the 20th century only four segments of windblown dunes were left in the Curonian Spit, a dramatic increase in the number of visitors to the dunes not overgrown with vegetation brought about significant relief transformations. At the initiative of the Curonian Spit National Park, since 2003 the monitoring of aeolian processes has been pur- 

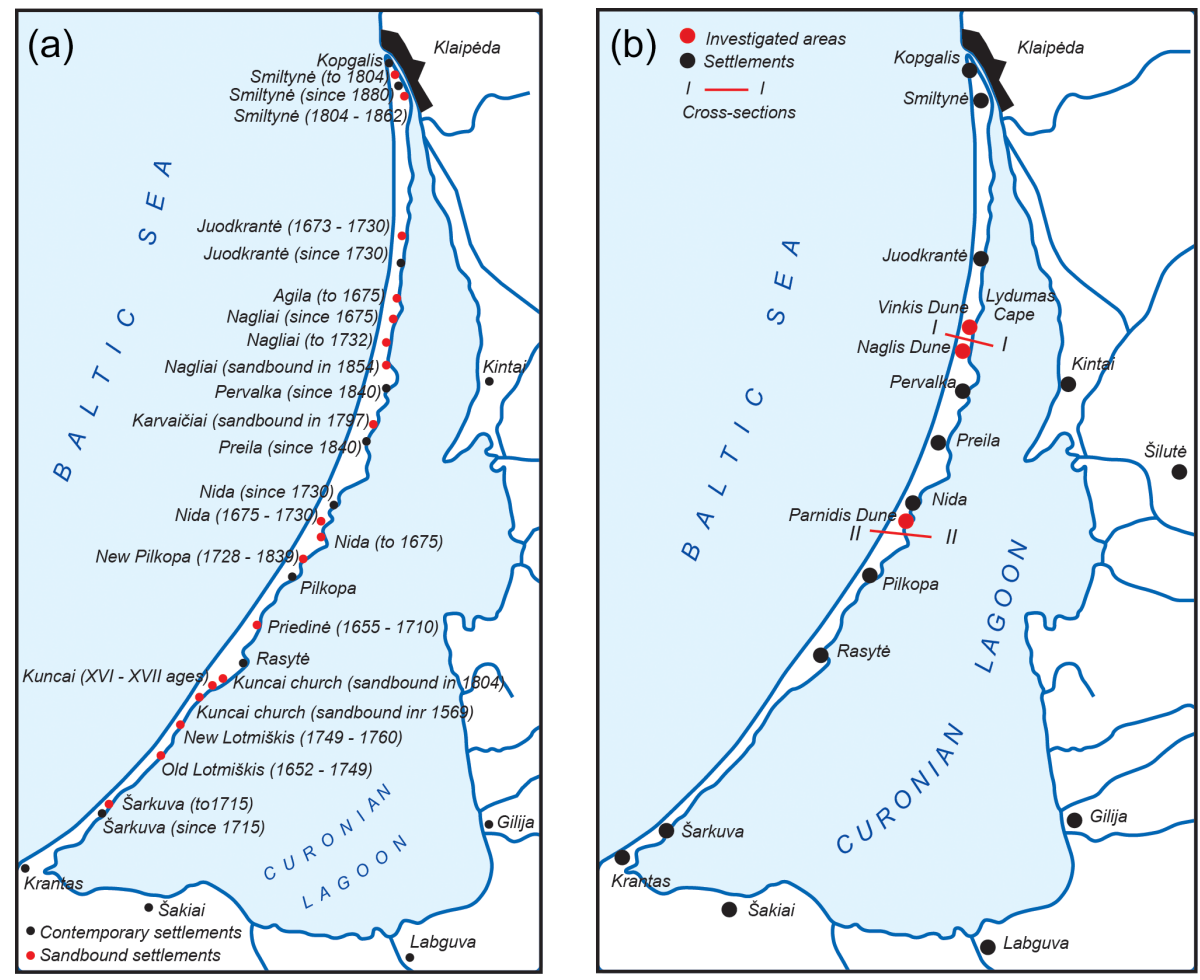

Figure 3. Contemporary and extinct settlements (a) and investigated areas (b). Places of cross sections: I-I - Vingiakopé environment (Fig. 1); II-II - Parnidis environment (Fig. 4).

sued in the Lithuanian part of the Curonian Spit, which enables identifying regularities of changes in aeolian deflation and accumulation processes (Morkūnaitè and Česnulevičius, 2005; Česnulevičius et al., 2016).

Currently, specific tectonic subsidence phenomena related to deformations of marl accumulated in the freshwater basin are taking place south of Nida settlement (Fig. 4). For this reason, marl squeeze formed on the coast of the Curonian Lagoon. Before the Second World War, Vladas Viliamas described the phenomena and pointed out a rather wide distribution of the phenomena south of Juodkrante settlement (Viliamas, 1932). In 1985, marl squeeze was still observed south of Juodkrantė (Kabailienè, 1997). To date, marl can only be detected south of Nida. The pressure of a sand layer on the plastic marl layers causes deformations on the surface of dunes and gives rise to the formation of stepwise microterraces. Such geological-geomorphological formations can also be found in other areas of the Baltic Sea (Lampe et al., 2011; Sergeev et al., 2016).

The purpose of this article is to assess quantitative changes of aeolian relief forms induced by alterations of climate components in the wind-blown areas of the Curonian Spit.

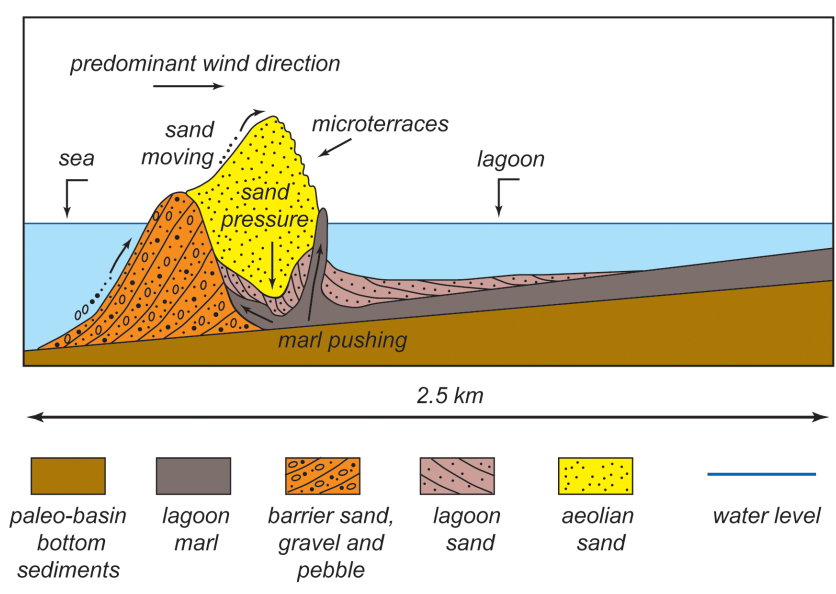

Figure 4. Lagoon marl layer deformation model in the investigated area (by Sergeev et al., 2016.).

\section{Methods}

The intensity of aeolodynamic processes was assessed using repeated precise levellings in the reference strips of windblown dunes and analysing the digital topographical largescale maps $(1: 5000)$ of 2004, topographical maps of 1911 and 1940, orthophoto images of 2009 and 2014, and aerial photographs taken from an unmanned aerial vehicle in 2015- 
2016. Investigations were carried out in the Lithuanian part of the Curonian Spit: Parnidis, Naglis, and Vinkis dunes (Fig. 3b), where a repeated precise levelling of wind-blown sand strips of the ridge was performed. The levelling was done with the help of an ELTA 500 electronic tacheometer and Trimble GeoXT 6000 GPS with an accuracy of 5 arcsec for measuring angles and $1 \mathrm{~mm}$ for measuring elevations of points. A comparison of repeated levelling profile data enabled quantitative assessment of changes in the main dune ridge relief forms. The mapping of the surface of dunes was done using an unmanned aerial vehicle (DJI Inspire).

An analysis of aeolian microform variations (depressions, hummocks, gullies, ridges) was carried out in a wind-blown sand strip of Naglis and Vinkis dunes. Quantitative changes of microforms that occurred in the period of 1999-2016 were compared. The morphometric microform indices were obtained by performing route measurements from natural benchmarks and using a GPS receiver and a $\pm 1 \mathrm{~mm}$ accuracy distance measurer (Leica Disto D510).

An assessment of dune surface changes was made based on meteorological factors: the beginning and end of strong wind periods and the moisture of the surface sand layer. An analysis of sand samples taken from the surface sand layer and at a depth of $0.15 \mathrm{~m}$ in windward and leeward dune slopes enabled determining the beginning of local and massive wind-blown sand movements. Sand moisture and groundwater level in the dunes were estimated using georadar scanning data (Dobrotin et al., 2013).

To specify in greater detail the periodicity and intensity of wind-blown sand movements, an analysis of climatic parameters (wind speed, wind direction, air temperature, and precipitation) from meteorological stations of Klaipeda, Nida and Šilute for the period 1991-2015 was performed: in addition, the data from a temporary meteorological station established on the seacoast of Nida for the summer of 2016 were used. The assessment of climatic parameters was necessary for the purpose of forecasting possible meteorological situations. Unfavourable weather conditions (wind, rain, snow) made a direct impact on the flight of an unmanned aerial vehicle and the quality of aerial photographs.

To measure the local wind regime in the coastal area of the Baltic Sea, a temporary mobile meteorological station was established. It operated only in the summer of 2016. The data about wind speed, wind direction, air temperature, and precipitation taken by self-recorders of the station were compared with the data from the Nida meteorological station, and correlation indices were determined. Occasional wind speed measurements were also taken by an unmanned aerial vehicle. A comparison of short-term and occasional measurements of wind speed and direction with the data of meteorological stations allows stating that the wind regime recorded at the Klaipeda meteorological station was closest to the wind regime recorded in the dune ridge of the Curonian Spit. The correlation coefficient was equal to $r=0.988$ for wind speed and $r=0.998$ for wind direction.

\section{Climatic factors}

An analysis of 30-year data of climatic factors from meteorological stations of Nida, Klaipeda, and Šilute enabled distinguishing the greatest periods of aeolian processes. In particular, three main factors that made a direct impact on aeolian processes, i.e. wind regime, precipitation, and air temperature, were analysed.

Compared with the remaining territory of Lithuania, the Curonian Spit distinguishes by a specific climate with mild and often snowless winters, frequent strong winds and storms, a longer period of above-zero temperatures. We described the climate of the northern part of the Curonian Spit based on the data from the Klaipeda meteorological station and the climate of the central part of the spit based on the data from Nida and Šilute meteorological stations.

Air temperature was an important factor affecting aeolian processes. In the cold season of the year, aeolian processes were very slow and occurred only with storm winds. Due to low temperature, the surface of moist sand got frozen and the crust formed, which protected sand from being blown by wind. The cold season of the year lasted from 18 (19911992) to 114 (1995-1996) days. Cold seasons were often accompanied by thaw periods when the frozen sand crust lost its stiffness and aeolian processes revived. The thawing of the sand crust required longer (4-16 days) periods of temperatures above zero $\left(1-4{ }^{\circ} \mathrm{C}\right)$. Such situations were recorded in 1986-1987, 1989-1990, 1992-1993, 1999-2000, and 20082009. In 1991-1992, when temperatures above zero prevailed, no sand crust formed and aeolian processes could take place all year round.

The amount and temporal distribution of precipitation were other important factors affecting aeolian processes, in particular, the number and duration of periods without precipitation. An analysis of 30-year data of precipitation from Nida, Klaipeda, and Šilutè meteorological stations showed that dry periods were distributed rather evenly throughout a year. Dry periods without precipitation lasted for, on average, 15 days in spring (March-May), 13 days in summer (JuneAugust), and 10 days in autumn (September-November). However, dry periods differed between years. For example, the period without precipitation lasted 30 days (entire May month) in the spring of 1992, 25 days (nearly all the month of May) in the spring of 2000, and 26 days (nearly all the month of April) in 2009. In spring, the minimum duration of the period without precipitation was 6 days, and the maximum 30 days. In summer, the longest period without precipitation lasted 29 days (July 1994), and the shortest 5 days. In autumn, the longest periods without precipitation were recorded in 1998 (21 days in September-October) and 2005 (19 days in October).

Wind was the main climatic factor affecting aeolian processes. Wind speed, direction, and duration of blowing varied between different seasons of the year (Fig. 5). An analysis of multiannual weather parameters from the Nida meteorolog- 
(a)

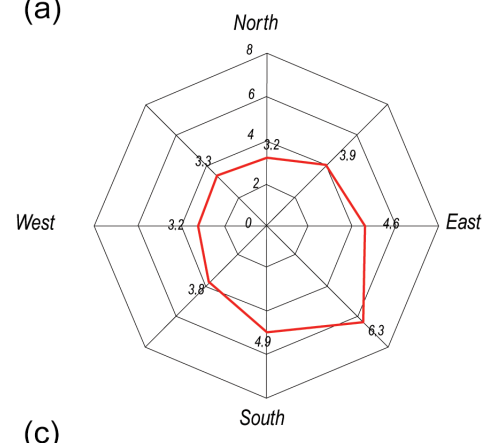

(c)

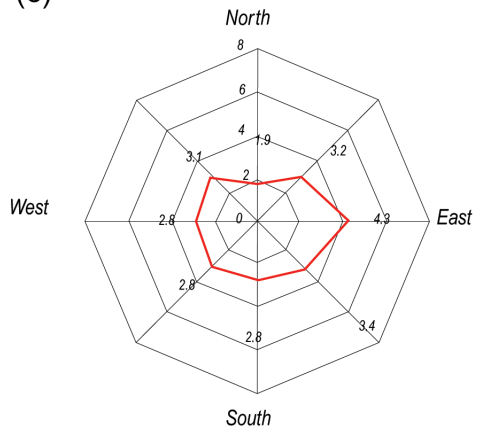

(e)

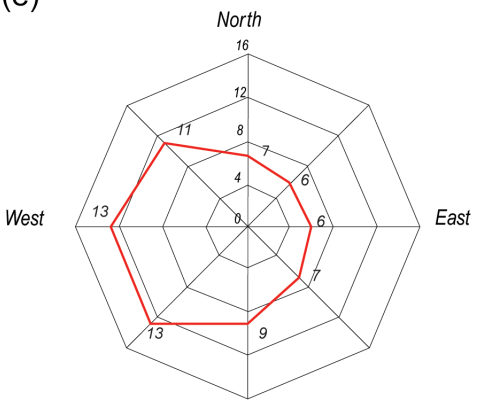

(b)

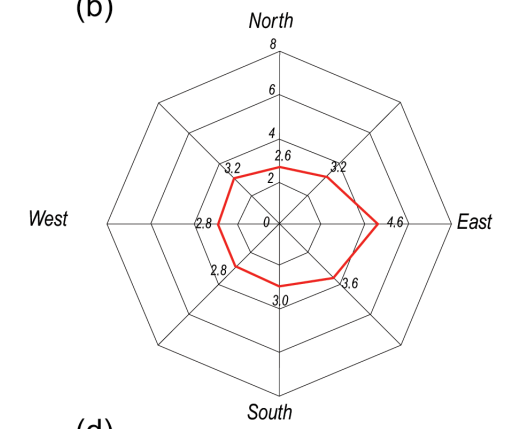

(d)

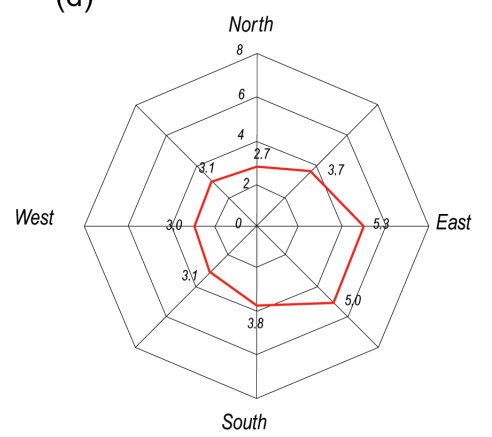

(f)

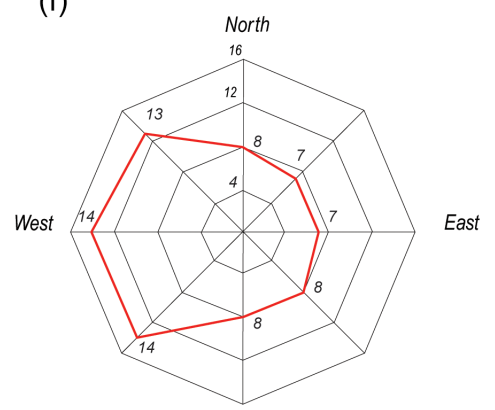

Figure 5. Multiannual average wind speed registered at meteorological stations in Nida, Šilute and Klaipèda: (a) December-February (Nida); (b) March-May (Nida); (c) June-August (Nida); (d) September-November (Nida); (e) multiannual maximum wind speed (Šilute); (f) multiannual maximum wind speed (Klaipèda).

ical station showed that the Curonian Lagoon made a great impact on wind dynamics. E-SE-S winds with an average speed of 5-6 m s${ }^{-1}$ prevailed in all years. According to the data from the Nida station, the maximum speed of winds lasting $3 \mathrm{~h}$ and longer reached $16 \mathrm{~m} \mathrm{~s}^{-1}$ in spring, $16 \mathrm{~m} \mathrm{~s}^{-1}$ in summer, $22 \mathrm{~m} \mathrm{~s}^{-1}$ in autumn, and $21 \mathrm{~m} \mathrm{~s}^{-1}$ in winter. According to the data from the Klaipeda seacoast meteorological station, SW-W-NW winds with an average speed of $5.0 \mathrm{~m} \mathrm{~s}^{-1}$ prevailed. The maximum speed of $3 \mathrm{~h}$ winds taken at the Klaipeda hydrometeorological station was considerably greater: $20 \mathrm{~m} \mathrm{~s}^{-1}$ in spring (2000), $18 \mathrm{~m} \mathrm{~s}^{-1}$ in summer (1981 and 2002), $26 \mathrm{~m} \mathrm{~s}^{-1}$ in autumn (1981), and $26 \mathrm{~m} \mathrm{~s}^{-1}$ in winter (1982). Among maximum wind speeds, N (51\% of cases), SW (38\%), and SE (11\%) winds prevailed. The maximum wind speeds of other directions constituted less than $1 \%$. According to the data from the Šilute meteorological station, the maximum wind speed reached $17 \mathrm{~m} \mathrm{~s}^{-1}$ in spring,
$13 \mathrm{~m} \mathrm{~s}^{-1}$ in summer, $21 \mathrm{~m} \mathrm{~s}^{-1}$ in autumn, and $18 \mathrm{~m} \mathrm{~s}^{-1}$ in winter.

The strong wind due large dune surface changes. The number of days with higher than $15 \mathrm{~m} \mathrm{~s}^{-1}$ wind speed was 55 . The last decade was "softer" than the period 1993-2002, when there were 63 such days, or the period 1981-1990, when there were 75 such days. The most obvious change of dunes surface was after a strong storm winds. Over the last 30 years the most powerful hurricanes were in 1993 (wind speed reached $34 \mathrm{~m} \mathrm{~s}^{-1}$ ), 1999 (hurricane Anatoly, $40 \mathrm{~m} \mathrm{~s}^{-1}$ ), 2005 (hurricane Ervin, $34 \mathrm{~m} \mathrm{~s}^{-1}$ ), and 2011 (hurricane Joachim, $28 \mathrm{~m} \mathrm{~s}^{-1}$ ).

The storms influence extreme values of sea and lagoon level when the water level raised higher than $100 \mathrm{~cm}$ above mean water level. In the end of the 20th century strong storms were more frequent than in the middle of the century, which resulted in a higher water level in the Curonian Lagoon (Dai- 
Table 1. Wind speed and number of cases in March-October 2016 year (data from the Nida meteorological station).

\begin{tabular}{lrr|lrrr}
\hline & \multicolumn{2}{l}{ Total wind } & Wind over $6 \mathrm{~m} \mathrm{~s}^{-1}$ speed & & \\
\cline { 2 - 5 } $\begin{array}{l}\text { Wind } \\
\text { direction }\end{array}$ & cases & $\%$ & cases & $\%$ & $\begin{array}{r}\text { Maximum speed } \\
\text { in gust, } \mathrm{m} \mathrm{s}^{-1}\end{array}$ & $\begin{array}{r}\text { Duration, in } \\
\text { hours }\end{array}$ \\
\hline $\mathrm{N}$ & 273 & 20 & 259 & 95 & 24.7 & 819 \\
$\mathrm{NE}$ & 117 & 9 & 109 & 92 & 24.7 & 819 \\
$\mathrm{E}$ & 104 & 8 & 99 & 94 & 24.3 & 354 \\
SE & 81 & 6 & 81 & 100 & 25.5 & 315 \\
$\mathrm{~S}$ & 99 & 7 & 95 & 96 & 26.4 & 243 \\
SW & 213 & 15 & 212 & 99 & 29.8 & 297 \\
W & 245 & 18 & 239 & 98 & 26.6 & 639 \\
NW & 239 & 17 & 228 & 95 & 26.5 & 735 \\
\hline
\end{tabular}

lidiené et al., 2006; Jarmalavičius et al., 2014, 2016). The raised water washed the foot and of the dunes and destabilized middle part of slopes.

The recorded differences in wind regime were due to the location of meteorological stations: the Klaipèda and Šilute meteorological stations were exposed to the winds of all directions, whereas the Nida meteorological station was located at the foot of the dune ridge of the Curonian Spit, and the dune ridge blocked EW-W-NW winds.

\section{Results and discussion}

Our analysis was based on the data of wind speeds exceeding $6 \mathrm{~m} \mathrm{~s}^{-1}$ as recorded at Nida, Klaipeda and Šilutè meteorological stations in the warm periods (March-October) of 19842015. During the investigation period, W-NW (16.8\%), W $(14.0 \%), \mathrm{S}(3.7 \%)$, and $\mathrm{E}(2.7 \%)$ winds prevailed among wind speeds over $6 \mathrm{~m} \mathrm{~s}^{-1}$, which constituted $13.7 \%$ of all cases. The Klaipeda meteorological station recorded a total of 55 cases of very strong winds (over $15 \mathrm{~m} \mathrm{~s}^{-1}$ ) in 20062015 (a shorter period of strong winds), 75 cases of very strong winds in 1984-1994 (a long period of very strong winds), and 63 cases in 1995-2005 (a medium-duration period of very strong winds). In 2006-2015, 60 cases of very strong winds were recorded at the Nida station and 43 cases at the Šilute station. The warm period of 2016 in the Curonian Spit was particularly windy. According to the data from the Nida meteorological station (wind speed and direction were measured every $6 \mathrm{~h}$ ), winds were recorded to blow for a total of $4221 \mathrm{~h}$, and winds stronger than $6 \mathrm{~m} \mathrm{~s}^{-1}$ were recorded to blow for $3966 \mathrm{~h}$ during the warm season (Table 1).

Permanent strong winds caused fast sand drying and intensified deflation processes. Our measurements showed that $1 \mathrm{~h}$ after rain the surface sand layer was about $50 \%$ drier compared with sand at a depth of $10 \mathrm{~cm}$ (Table 2).

Sand moisture was measured by the method of weighing dishes in different dune profile areas, and a comparison was made between sand moisture in the Parnidis Dune environs of 16 June 2016 (amount of precipitation: $2.3 \mathrm{~mm}$ ) and in the Vinkis Dune environs of 18 June of the same year (amount of precipitation: $1.5 \mathrm{~mm}$ ) (Table 2). In the western part of the Vinkis Dune, sand moisture reached $1.91-2.74 \%$ on the surface and $1.83-2.39 \%$ at a depth of $10 \mathrm{~cm}$. In the nature trail, sand moisture was $0.22 \%$ on the surface and 0.065 at a depth of $10 \mathrm{~cm}$. Such inverse distribution could be due to human trampling. In May 2014, no moisture distribution inversion was detected on sand surface or in deeper layers: on 12 May (amount of precipitation: $2.1 \mathrm{~mm}$ ) sand moisture reached $3.41 \%$ on the surface and $5.04 \%$ at a depth of $15 \mathrm{~cm}$ near the nature trail up the Nagliai Dune (fewer visitors). The sand moisture measurement data obtained near the Parnidis Dune on 27 June 2015 (amount of precipitation: $1.9 \mathrm{~mm}$ ) were more consistent, because in the western part of the slope there was a tussock area where sand contained more moisture (by 1-2\%) compared to the sand near the top.

Because of an constant stream of visitors, the crest of the southern segment of the dune ridge of the Lithuanian part of the Curonian Spit (Parnidis and Slandytojai dunes) is completely trampled. Small natural deflation hollows have survived only in the distal slope facing the Curonian Lagoon. Such hollows are most severely affected by S-SE winds prevailing in spring (May) and winter (December-February). SSE winds in the summers of 2004-2016 markedly changed the form and depth of deflation hollows. The changes constituted up to $0.05-0.20 \mathrm{~m} \mathrm{day}^{-1}$.

The relief microforms reflecting the intensity of short-term deflation processes have formed in nearly all investigated deflation and accumulation hollows in the northern JuodkrantèPervalka segment. Scraps (up to $2 \mathrm{~m}$ height and up to $40^{\circ}$ inclination), deflation mini-gullies, potholes, accumulative steps, small ridges, and rolls formed in the hollows. Deflation hollows were found to be mostly distributed between the Lydumo ragas peninsular and Vinkis Dune. The deflation hollows were 35-40 $\mathrm{m}$ a.s.1., which shows that the best conditions for deflation were on the top of the dune ridge severely affected by $\mathrm{W}$ winds. 
Table 2. Distribution of sand moisture on the surface and at a depth of $10 \mathrm{~cm}$ in the environs of Parnidis and Naglis dunes.

\begin{tabular}{|c|c|c|c|c|}
\hline \multirow[b]{2}{*}{ Location } & \multirow[b]{2}{*}{ Coordinates, $\mathrm{m}$} & \multicolumn{2}{|c|}{ Moisture, \% } & \multirow[b]{2}{*}{ Precipitation, $\mathrm{mm}$} \\
\hline & & On the surface & $10 \mathrm{~cm}$ deep & \\
\hline \multicolumn{5}{|c|}{ Parnidis Dune } \\
\hline Western slope foot & $\begin{array}{l}X=6133110 \\
Y=3086571\end{array}$ & 2.24 & 5.01 & 2.3 \\
\hline Western slope & $\begin{array}{l}X=6132967 \\
Y=3087035\end{array}$ & 5.74 & 4.02 & 2.3 \\
\hline \multicolumn{5}{|c|}{ Naglis Dune } \\
\hline Western slope foot & $\begin{array}{r}X=6150431 \\
Y=315518\end{array}$ & 1.84 & 3.93 & 1.5 \\
\hline Western slope & $\begin{array}{r}X=6150432 \\
Y=315788\end{array}$ & 2.38 & 1.96 & 1.5 \\
\hline Top & $\begin{array}{r}X=6150463 \\
Y=316129\end{array}$ & 0.25 & 0.45 & 1.5 \\
\hline Eastern slope & $\begin{array}{r}X=6150433 \\
Y=316441\end{array}$ & 1.61 & 0.15 & 1.5 \\
\hline Eastern slope foot & $\begin{array}{r}X=6150459 \\
Y=316492\end{array}$ & 1.53 & 2.91 & 1.5 \\
\hline
\end{tabular}

Deflation hollows formed in each seaward or lagoon-ward relief depression in the Lydumo ragas-Vinkis Dune segment. We compared the measurements of 1999-2016 and found that the length and width of deflation hollows were the most variable parameters. Moreover, the length and width of passages connecting the hollows were also very dynamic. They could change by some to several dozens of metres per year (Table 3). In the Juodkrantė-Pervalka segment, the blowing of sand away from hollows was due not only to frequent strong winds but also to the position of hollows in dune slopes. The strongest deflation processes took place in the hollows located in the leeward eastern slopes of the dune ridge. The hollows in the crest of the dune ridge were blown out to a lower degree, and the hollows in the windward western slope of the dune ridge suffered the lowest degree of deflation. The degree of deflation also depended on whether hollows were open or closed. The hollows with W-E deflation passages opening thereto suffered the fastest transformations. The wind quickly transformed such hollows into deflation gullies.

Further to the south, the Parnidis Dune sand layer is pressing a freshwater marl layer beneath and forming an up to $2 \mathrm{~m}$ high squeezed scrap on the coast of the Curonian Lagoon. The pressure causes the formation of micro-terraces on the slope of the dune. The development of micro-terraces is closely related to infiltration of precipitation into the sand layer. The pressure of the sand layer increases in spring, when snow is melting, and in summer and autumn, when precipitation is abundant. This causes changes in morphometric parameters of micro-terraces on a stable slope of the dune ridge south of the Parnidis Dune. In April and
Table 3. Transformation of aeolian deflation relief forms in 19992015.

\begin{tabular}{lrrrr}
\hline & \multicolumn{4}{c}{ Length/width, m } \\
\cline { 2 - 5 } Aeolian form & 1999 & 2001 & 2003 & 2016 \\
\hline Scarp & $6.6 / 2.0$ & $7.1 / 2.4$ & $6.6 / 1.7$ & $6.8 / 1.8$ \\
Hollow & $30.3 / 13.2$ & $34.6 / 16.4$ & $28.7 / 14.8$ & $35.6 / 18.3$ \\
Passage & $30.0 / 4.0$ & $42.0 / 7.6$ & $34.0 / 6.3$ & $47.0 / 11.8$ \\
Roll & $29.0 / 5.0$ & $30.5 / 5.5$ & $31.0 / 4.8$ & $34.0 / 5.9$ \\
Ledge & $15.4 / 8.5$ & $17.2 / 7.6$ & $19.6 / 9.4$ & $22.6 / 11.4$ \\
Pothole & $25.6 / 8.2$ & $39.3 / 11.2$ & $42.0 / 13.8$ & $46.2 / 15.6$ \\
\hline
\end{tabular}

September 2015-2016, the slope was photographed four times from an unmanned aerial vehicle. Upon creation of a three-dimensional surface model, the relief microforms were measured. The measurements were taken in the photographs of different periods where the spatial position of the same points was precisely identified (Fig. 6).

The measurements showed that the position of microterraces changed during a 5-month period. A comparison of the measurement results of aerial photographs between April and September 2016 revealed a decline in the height of terrace ledges by $0.50-0.64 \mathrm{~cm}$. An increase in the height of the terrace ledge in the middle part of the slope was due to a sand slide made by numerous visitors to the dunes.

The height of the coastal scrap at the foot of the slope increased by $0.42 \mathrm{~m}$ thanks to the marl squeeze. Similar changes occurred on the eastern slope of the Sklandytojai Dune located on the Lithuanian-Russian border, where the 


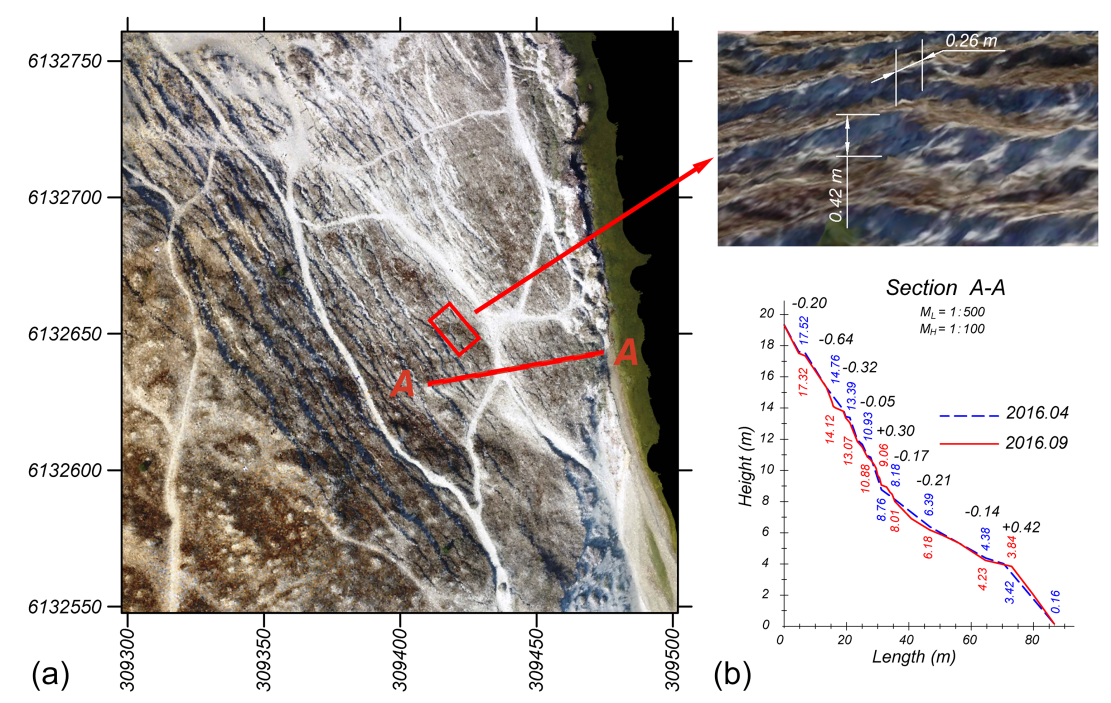

Figure 6. Investigation areas (left) and changes in micro-terrace parameters (right).

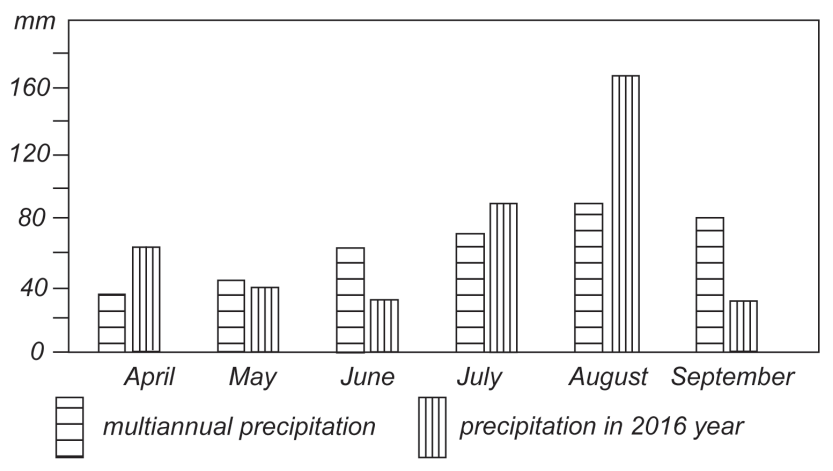

Figure 7. Comparison of multiannual and annual (2016 year) summer precipitation (from Nida meteorological data).

height of the coastal marl scrap increased by $0.5 \mathrm{~m}$ during the spring-summer period of 2016.

Rather sharp changes in micro-terraces of eastern slopes were related to the amount of precipitation exceeding the average. In April-September 2016, precipitation amount exceeded the multiannual average by $110 \%$. Still greater differences were observed in July-August 2016, when the amount of precipitation exceeded the multiannual average by $160 \%$ (Fig. 7).

We can state that in the end of summer the pressure of moist sand on the marl layer increased 1.6-fold, which conditioned a particularly marked change in the position of microterraces. Somewhat smaller changes took place after the winter of 2015-2016, when infiltration of thawed snow water into sand sharply increased at the beginning of March. Since the autumn of 2015 , the changes in the vertical position of terrace ledges have constituted $0.12-0.56 \mathrm{~m}$ on average.

\section{Conclusions}

1. The deflation processers in the northern part of the Curonian Spit were mostly affected by frequent strong SW-W-NW winds of the maximum speed of 18$26 \mathrm{~m} \mathrm{~s}^{-1}$, while the deflation processes in the middle part of the spit were mostly due to E-SE-S winds of $16-22 \mathrm{~m} \mathrm{~s}^{-1}$ maximum speed. Aeolian processes were largely influenced by long-lasting winds of the average speed exceeding $6 \mathrm{~m} \mathrm{~s}^{-1}$. The duration of such winds reached $4000 \mathrm{~h}$ in Nida in the March-October 2016. Strong permanent winds induced fast sand drying and activated deflation processes, which were further accelerated by a constant stream of visitors to the dunes.

2. In the northern segments of the Curonian Spit (Nagliai and Vinkis dunes), aeolian microforms (scraps, gullies, potholes, steps, small ridges and rolls) appeared in the deflation and accumulation hollows of $35-40 \mathrm{~m}$ in absolute height. Such microforms appeared in each deflation hollow on a windward or leeward slope of the dunes. The strongest deflation processes took place in the hollows of the northern slopes of the dune ridge exposed to winds blowing from the Curonian Lagoon. The hollows on the crest of the dune ridge experienced a lower deflation degree, and those in the western windward slope of the dune ridge suffered the lowest degree of deflation. The deflation process largely depended on whether the hollow was closed or open. The hollows with W-E deflation passages opening thereto underwent the greatest transformations. W winds quickly transformed such hollows into deflation gullies. 
3. The measurements of repeated aerial photographs showed that the change in morphometric parameters of micro-terraces was related to fluctuations in precipitation intensity. A greater infiltration of precipitation sharply increased the weight of the sand layer and its pressure on the marl layer. In the summer (July-August) of 2016, the amount of precipitation increased 1.6-fold compared with the multiannual average, which gave rise to changes in micro-terraces and in the scrap of the coastal marl. The sinking of terrace ledges reached $21 \%$, and marl scrap height increased by $25 \%$ in some places.

4. An investigation of geodynamic processes revealed the regularities and reasons of transformations of aeolian macro- (e.g. hollows), meso- (rolls) and micro-forms (e.g. micro-terraces). Changes in relief forms and their measurements confirm the "sensitivity" of aeolian sands of the Curonian Spit and the need for regulation of their protection. The abundance of visitors and their curiosity and activity make such regulation even more relevant. Such problematic places include Parnidis Dune, where visiting is unlimited, and Naglis Dune, where visiting is restricted and a fee must be payed. In other drifting dune areas, visiting is completely banned.

Data availability. The measurement of aeolian relief forms in Curonian Spit has been carried out by the authors since 1995. The dune shape changes data were collected by the authors (Regina Morkūnaitè, Algimantas Česnulevičius, Artūras Bautrenas), who are happy to provide data on request (algimantas.cesnulevicius@gf.vu.lt, morkunaite@geo.lt, arturas.bautrenas@gf.vu.1t). Some articles are based on this data analysis: Morkūnaitè et al. (2002, 2011, 2016), Česnulevičius and Morkūnaitè (1997), Morkūnaitè and Česnulevičius (1998, 2001, 2005), and Česnulevičius et al. (2006). Analysis of climate indicators analysis was performed using the data freely accessible from the Klaipeda, Nida and Šilute meteorological stations (Lithuanian Hydrometeorological Service), and meteorological data from the stations are available on request (http://www.meteo.lt/en/web/guest/applications). For the overview of historical dune changes, freely accessible archival maps were used (http://old.meteo.lt/stebejimu_tinklas.php). Metadata of the climatic parameters set can be found at http://www.meteo.lt/documents/20181/141122/Informacines_ rinkmenos/10b3be00-d496-4a5b-9938-0a4e80031879.

Competing interests. The authors declare that they have no conflict of interest.

Acknowledgements. The authors acknowledge the Lithuanian Hydrometeorological Service, which kindly allowed us to use the Klaipeda, Nida and Šilute meteorological station data.
Edited by: M. Reckermann

Reviewed by: two anonymous referees

\section{References}

Badyukova, E. N., Zhindarev, L. A., Lukyanova, S. A., and Soloveva, G. D.: Geological Structure of the Curonian Spit (of the Baltic Sea) and Its Evolution History (Revised), Oceanology, 47, 554-563, 2007.

Berendt G.: Geologie des Kurishen Haffes und seiner Umgebung, Albertina Universität, Königsberg, 1869.

Bitinas, A. and Damušytè, A.: The Littorina Sea at the Lithuanian maritime region, Polish Geological Institute Special Papers, 11, 37-46, 2004.

Bitinas, A., Damušytė, A., Hütt, G., Jaek, I., and Kabailienė, M.: Application of the OSL dating for stratigraphic correlation of Late Weichselian and Holocene sediments in the Lithuanian Maritime Region, Quaternary Sci. Rev., 20, 767-772, 2001.

Bitinas, A., Damušytė, A., Stančikaitè, M., and Aleksa, P.: Geological development of the Nemunas River Delta and adjacent areas, West Lithuania, Geol. Q., 46, 375-389, 2002.

Bitinas, A., Žaromskis, R., Gulbinskas, S., Damušytè, A., Žilinskas, G., and Jarmalavièius, D.: The results of integrated investigations of the Lithuanian coast of the Baltic Sea: geology, geomorphology, dynamics and human impact, Geol. Q., 49, 355-362, 2005.

Česnulevičius, A. and Morkūnaite, R.: Morphometrical, lithological and mineralogical traits of eolian formations in the Lithuanian coastal zone of the Baltic Sea, Baltica, 10, 53-58, 1997.

Česnulevičius, A., Izmailow, B., and Morkūnaitè, R.: Dynamics of deflation hollows in Main Dune Ridge of Curonian Spit, Geography, 42, 21-28, 2006.

Česnulevičius, A., Bautrènas, A., Morkūnaitè, R., and Kavoliutė, F.: Intensity of aeolian processes on Curonian Spit (the end of the XX century - begining the XXI century), Selected issues of aeolian geomorphology, Jagiellonian University, Cracow, Poland, 111-130, 2016.

Dailidienè, I., Davulienė, L., Tilickis, B., Stankevičius, A., and Myrberg, K.: Sea level variability at the Lithuania coast of the Baltic Sea, Boreal Environ. Res., 11, 109-121, 2006.

Dobrotin, N., Bitinas, A., Michelevičius, D., Damušytè, A., and Mažeika, J.: Reconstruction of the Dead (Grey) Dune evolution along the Curonian Spit, Southeastern Baltic, Bull. Geol. Soc. Finl., 85, 53-64, 2013.

Gaigalas, A. and Pazdur, A.: Chronology of buried soils, forest fires and extreme migration of dunes on the Kuršiu nerija spit (Lithuanian coast), Landform Analysis, 9, 187-191, 2008.

Gudelis, V.: The Quaternary History of the Baltic, Acta Universitatis Upsaliensis, 1, 159-173, 1979.

Gudelis, V.: The Lithuanian offshore and coast of the Baltic Sea, Academia, Vilnius, Lithuania, 1998.

Jarmalavičius, D., Pupienis, D., and Žilinskas, G.: Sea level fluctation and shoreline evolution on decadal time scale, Lithuanian Baltic Sea coast, J. Coast. Res., 70, 164-169, 2014.

Jarmalavičius, D., Šmatas, V., Stankūnavičius, G., Žilinskas, G., and Pupienis, D.: Factors controlling coastal erosion during storms events, J. Coast. Res., 75, 1112-1116, 2016.

Kabailiene, M.: Evolution of the Curonian Spit, Nemunas Delta and surrounding swamps, Proceedings of Geological Institute, 5, Vilnius, Lithuania, 181-207, 1967. 
Karte des Deutschen Reiches: $1: 100000$, K 3 II L 62, Blattnummer: 3, 8, 15, 16, 29, R. Eisenschmidt Verlags-Buhhandlung, Königsberg, 1911.

Kliewe, H. and Janke, W.: Der Holozane Wasserspiegelanstieg der Ostsee im Nordostlichen Kustengebiet der DDR, Petermanns Geographische Mitteilungen, 2, 62-74, 1982.

Kunskas, R.: On the evolution of Curonian Lagoon, Nemunas Delta and coastal marshes, History of Lakes, Vilnus, Lithuania, 391$411,1970$.

Lampe, R., Naumann, M., Meyer, H., Janke, W., and Ziekur, R.: Holocene evolution of the Southern Baltic Sea coast and interplay of sea-level variation, isostasy, accommodation and sediment supply, in: The Baltic Sea Basin, edited by: Harff, J., Björck, S., and Hoth, P., 233-251, Spinger, Berlin, 2011.

Mardosienè, D.: Dynamics of High Dunes in the Curonian Spit, The Geographical Yearbook, 24, 114-119, 1988.

Michaliukaite, E.: Dynamics of Curonian Spit shores and dune by last 100 years, The Geographical Yearbook, 8, 97-115, 1967.

Minkevičius, V.: Eolic relief of the Baltic Sea cost, The Geographical Yearbook, 20, 156-160, 1982.

Minkevičius, V., Žilinskas, G., and Jarmalavičius, D.: Morphodynamic evaluation of protecting dune of Kuronian Spit, The Geographical Yearbook, 29, 63-74, 1996.

Mojski, E.: Development of the Vistula River Delta and evolution of the Baltic Sea: An attempt at chronological correlation, Geological Survey of Finland, 6, 39-51, 1988.

Morkūnaitė, R. and Česnulevičius, A.: Some aspectsof comparative characteristics of old and new generation of Curonian Spit dune, The Geographical Yearbook, 31, 200-211, 1998.

Morkūnaitė, R. and Česnulevičius, A.: Comparative characteristics of old and new generations of Curonian Spit dunes, Coastal dune management, Southport, 41-47, 2001.
Morkūnaite, R. and Česnulevičius, A.: Changes in blowout segments of the Main Ridge in the Curonian Spit in 1999-2003, Acta Zoologica Lituanica, 15, 145-150, 2005.

Morkūnaite, R., Šinkunas, P., Paškauskaite, J., and Cesnulevicius, A.: Wydmy i cechy granulometriczne piasków eolicznych obszaru Kazlu Ruda (poludniowo-zachodnia czesc Litwy), Utwory i formy eoliczne, Poznan, 16-24, 2002.

Morkūnaitè, R., Baužiene, I., and Česnulevičius, A.: Parabolic dunes and soils of the Curonian Spit, south-eastern Baltic Sea cost, Baltica, 24, 95-106, 2011.

Morkūnaite, R., Radžiuniene, J., Navickas, K., and Bautrenas, A.: Assessment of degradation of white and grey dune habitats in the Curonian Spit: A case study of Parnidis Dune (Nida environs, Lithuania), Zeitschrift für Geomorphologie, 60, 75-87, 2016.

Müller, A.: Late and Postglacial Sea-Level Change and Paleoenvironments in the Oder Estuary, Southern Baltic Sea, Quaternary Res., 55, 86-96, 2004.

Sergeev, A. Y., Zhamoida, V. A., Ryabchuk, D. V., Buynevich, I. V., Sivkov, V. V., Dorokhov, D. V., Bitinas, A., and Pupienis, D.: Genesis, distribution and dynamics of lagoon marl extrusions along the Curonian Spit, southeast Baltic Coast, Boreas, 46, 69$82,2016$.

Starkel, L.: Holocene palaeogeography, PWN, Warsaw, Poland, 1977.

Viliamas, V.: Curonian Spit: The climbing the dunes and their influence on homesteads, Sakalas, Kaunas, Lithuania, 1932. 